\title{
INFLUENCE OF DESIGN PARAMETERS OF A POLYPROPYLENE HOLLOW-FIBRE HEAT EXCHANGER ON ITS THERMAL PERFORMANCE
}

\author{
VPLIV PARAMETROV DIZAJNA TOPLOTNEGA \\ IZMENJEVALNIKA IZ POLIPROPILENSKEGA VOTLEGA \\ VLAKNA NA NJEGOVO TOPLOTNO UČINKOVITOST
}

\author{
Mária Čarnogurská ${ }^{*}$, Miroslav Př́íhoda ${ }^{2}$, Róbert Gallik ${ }^{1}$ \\ ${ }^{1}$ Technical University of Košice, Faculty of Mechanical Engineering, 04200 Košice, Slovakia \\ ${ }^{2}$ VSB - Technical University of Ostrava, Faculty of Materials Science and Technology, 70833 Ostrava-Poruba, Czech Republic
}

Prejem rokopisa - received: 2019-06-19; sprejem za objavo - accepted for publication: 2020-09-15

doi:10.17222/mit.2020.117

\begin{abstract}
The article presents potential applications of fibres made of polypropylene in new types of heat exchangers. It describes the properties of polypropylene and the method of sealing fibres in the potting process. An analysis was carried out to calculate the thermal capacity and pressure loss of the exchanger. An experimental stand was used to examine the heat transport in a shell-and-tube exchanger in a counter-flow set-up. Measurements were carried out with several designs of this type of exchanger comprising transparent as well as porous fibres. The experiment confirmed that transparent fibres in an exchanger provide heat transfer that is $20 \%$ better than that of the porous fibres. In the case of an exchanger comprising 1400 transparent fibres with an outer diameter of $0.275 \mathrm{~mm}$, the overall heat-transfer coefficient $k$, at a flow rate of secondary water of $150 \mathrm{~L} \cdot \mathrm{h}^{-1}$, was found to be $603 \mathrm{~W} \cdot \mathrm{m}^{-2} \cdot \mathrm{K}^{-1}$. With the use of "whirlers" on the outer side of fibres, the $k$ value elevated to $933 \mathrm{~W} \cdot \mathrm{m}^{-2} \cdot \mathrm{K}^{-1}$, and at a flow rate of $200 \mathrm{~L} \cdot \mathrm{h}^{-1}$, the heat-transfer coefficient amounted to as much as $1191 \mathrm{~W} \cdot \mathrm{m}^{-2} \cdot \mathrm{K}^{-1}$.

Keywords: polypropylene fibres, heat exchanger, experimental research, heat transfer

V članku je predstavljena možnost uporabe vlaken, izdelanih iz polipropilena v novih tipih toplotnih izmenjevalnikov. Opisuje lastnosti polipropilena in način pritrditve vlaken v postopku t. i.: potting-a. Analiziran je izračun toplotne moči izmenjevalnika in izguba tlaka $\mathrm{v}$ izmenjevalniku. Na stojalu za eksperimente je bil preverjen prenos toplote pri izmenjevalniku tipa Tube and Shell v protitočni povezavi. Izmerili smo več konstrukcij tega tipa s prozornimi in poroznimi vlakni. Poskus je potrdil, da prozorna vlakna $\mathrm{v}$ izmenjevalniku $\mathrm{v}$ primerjavi s poroznimi vlakni zagotavljajo boljši prenos toplote $\mathrm{za}$ do $20 \%$. Za izmenjevalnik s 1400 prozornimi vlakni z zunanjim premerom $0,275 \mathrm{~mm}$, je bil pri pretoku sekundarne vode $150 \mathrm{~L} \cdot \mathrm{h}^{-1} \mathrm{določen}$ koeficient prenosa toplote $k 603 \mathrm{~W} \cdot \mathrm{m}^{-2} \cdot \mathrm{K}^{-1}$. Pri uporabi turbulatorjev" na zunanji strani vlaken se je vrednost $k$ povečala na $933 \mathrm{~W} \cdot \mathrm{m}^{-2} \cdot \mathrm{K}^{-1}$, pri pretoku $200 \mathrm{~L} \cdot \mathrm{h}^{-1}$ pa je vrednost koeficienta prenosa toplote dosegla $1191 \mathrm{~W} \cdot \mathrm{m}^{-2} \cdot \mathrm{K}^{-1}$.

Ključne besede: polipropilenska vlakna, izmenjevalnik toplote, poskusne raziskave, prenos toplote
\end{abstract}

\section{INTRODUCTION}

Several scientific centres investigate the new category of heat exchangers, in which the heat-transfer surface consists of polypropylene (PP) fibres. ${ }^{1}$ The ongoing investigation is focussed on the possibilities of the production of such fibres and the quality of pots, in which they are sealed. ${ }^{2}$ The efforts are aimed at identifying the maximum temperatures for a safe operation of such exchangers $^{3-6}$ and analysing the potential for manufacturing exchangers with the largest possible heat-transfer surface area and thus also the highest possible heat-transfer performance. ${ }^{7}$ Tests are carried out to examine the quantity of the water flowing through the hollow fibres as well as the overall heat-transfer coefficient for the transfer of heat from the surrounding medium to the water flowing inside the fibres ${ }^{8}$ or potentially also the pressure loss. ${ }^{2}$ The investigation is also focussed on potential designs of heat exchangers. ${ }^{9}$

*Corresponding author's e-mail:

maria.carnogurska@tuke.sk (Mária Čarnogurská)
The purpose of the analyses of the above scientific papers was to examine the potential to apply the heat exchangers made of PP fibres in order to recover low-potential heat. This would facilitate, for example, the use of heat from communal or industrial waste waters. Due to a high degree of pollution of such waters, it is not possible to use conventional heat exchangers in such cases.

Currently designed heat exchangers must meet a wide range of requirements regarding the production technology, faultless operation and cost-efficiency. The key requirements generally placed upon heat exchangers include a high heat-transfer coefficient, low pressure loss, easy cleaning of the heat-transfer surface, resistance to corrosion with various types of transported media, adaptability of the exchanger design to particular production capacities and reasonable price. ${ }^{10,11}$ Heat exchangers for industrial applications are currently made of steel or other metals, less frequently of plastics or PP fibres.

The advantage of plastic exchangers is a long service life of the material (as much as 50 years), resistance to corrosion, chemicals and bacteria, as well as good hy- 
giene and low volumetric weight. However, heat exchangers of this type exhibit lower strength than metal exchangers, lower resistance to higher temperatures and mechanical damage, and lower quality of joints.,

At present, it is more and more frequent to use plastic heat exchangers with simple designs (Figure 1). More recent types of plastic exchangers resist to temperatures of up to $150{ }^{\circ} \mathrm{C}$ and exhibit good chemical resistance (they prevent diffused oxygen from penetrating the heat-transfer medium).

\section{MATERIALS AND METHOD}

PP exhibits good stability, strength and hardness, but its impact strength is low. Its properties may be affected, for example, by high doses of $\beta$ radiation. ${ }^{12}$ The modulus of elasticity of PP, which was exposed to radiation at a dose of $45 \mathrm{kGy}$ increased by as much as $54 \%$. The elasticity decreased from $10 \%$ to $7.9 \%$. PP is not prone to inner tension and is well weldable. However, a disadvantage of PP is that at low temperatures it becomes brittle. It may be used at temperatures between $-10{ }^{\circ} \mathrm{C}$ and $+100{ }^{\circ} \mathrm{C}$. It exhibits high electrical resistance and low thermal conductivity, which amounts to approximately $0.25 \mathrm{~W} \cdot \mathrm{m}^{-1} \cdot \mathrm{K}^{-1}$. At higher temperatures, plastic exchangers made of polyether ether ketone (PEEK) fibres are used. The exchangers comprising this type of fibres may be operated at temperatures of up to $220{ }^{\circ} \mathrm{C}$.

These fibres are manufactured with the technique of continuous pouring of liquid PP from an extruder. Then a fibre (capillary) is stretched and cooled in the air flow while its inner diameter decreases to values in the order of $10^{-1} \mathrm{~mm}$ (Figure 2). PP fibres with porous walls, containing 30-50\% of air, are also used. They are manufactured by repeating cycles of heating and stretching the capillaries.

Fibres are joined into bundles and their ends are sealed in pots (Figure 3). The number of fibres in one pot with a diameter of $20 \mathrm{~mm}$ may be as high as 1500 . Potting requires three materials: PP fibres, a PVC tube and a sealant. A great emphasis is put on the pot integrity, which is verified by testing the pot tightness at vari-

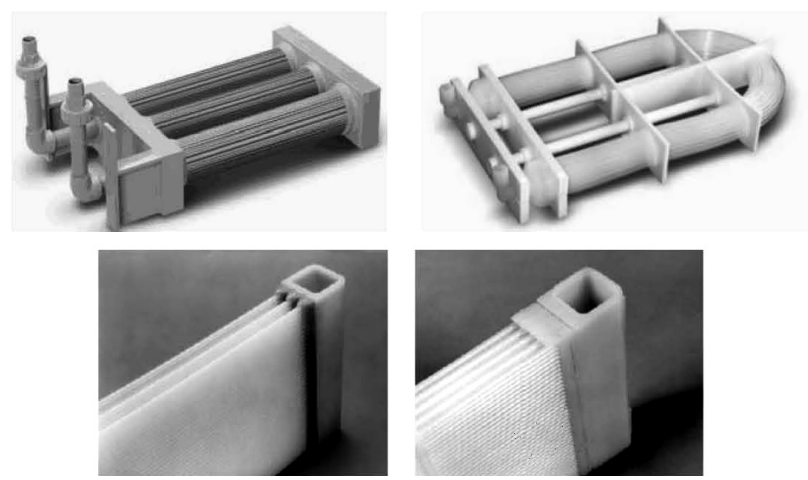

Figure 1: Plastic heat exchangers: a) three-bundle design, b) U-design, c) basic modules

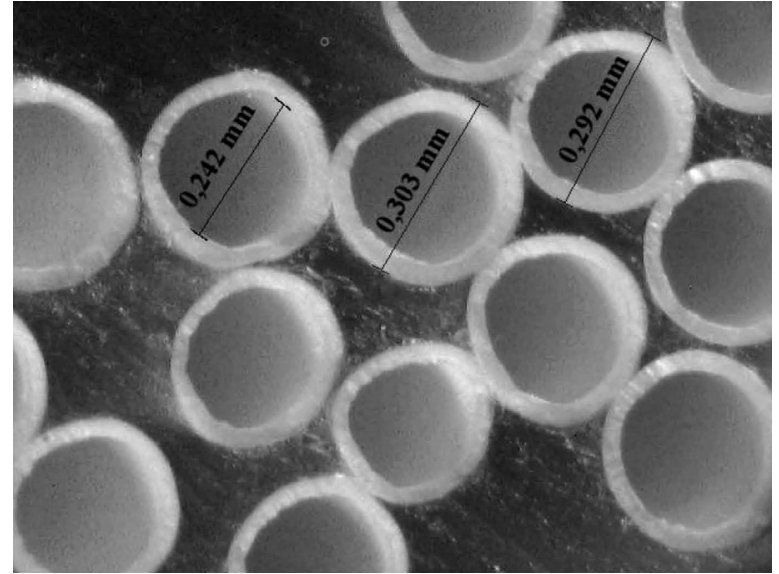

Figure 2: A bundle of polypropylene fibres

ous temperatures and pressures. The test output is the number of cycles, i.e., the number of immersions of a bundle of capillaries into cold and hot water, without compromising the tightness. The temperature of water and water pressure against the inner side of the capillaries depend on the intended application of the exchanger in a real operation. The wall thickness of individual fibres varies in a chaotic manner. It is affected by the technology used in the fibre production and most frequently it amounts to $50 \mu \mathrm{m}$.

The parameter subjected to the examination carried out with the PP fibres was the thermal capacity $P$ which was calculated using the following formula: ${ }^{11}$

$$
P=k \cdot \overline{\Delta T} \cdot S=Q_{\mathrm{m} 2} \cdot c_{\mathrm{p}} \cdot\left(T_{2}^{\prime \prime}-T_{2}^{\prime}\right)(\mathrm{W})
$$

where $k$ is the overall heat-transfer coefficient $\left(\mathrm{W} \cdot \mathrm{m}^{-2} \cdot \mathrm{K}^{-1}\right) ; \overline{\Delta T}$ is the mean temperature difference $(\mathrm{K}) ; Q_{m 2}$ is the mass flow rate of water in the secondary circuit $\left(\mathrm{kg} \cdot \mathrm{s}^{-1}\right) ; S$ is the heat-transfer surface area $\left(\mathrm{m}^{2}\right)$; $c_{p}$ is the specific heat capacity of water $\left(\mathrm{J} \cdot \mathrm{kg}^{-1} \cdot \mathrm{K}^{-1}\right) ; T_{2}^{\prime \prime}$ and $T_{2}^{\prime}$ are the temperatures of water entering and exiting the secondary circuit $\left({ }^{\circ} \mathrm{C}\right)$.

Using the obtained values of the parameters from Equation (1), the overall heat-transfer coefficient was identified using the following Equation (2):

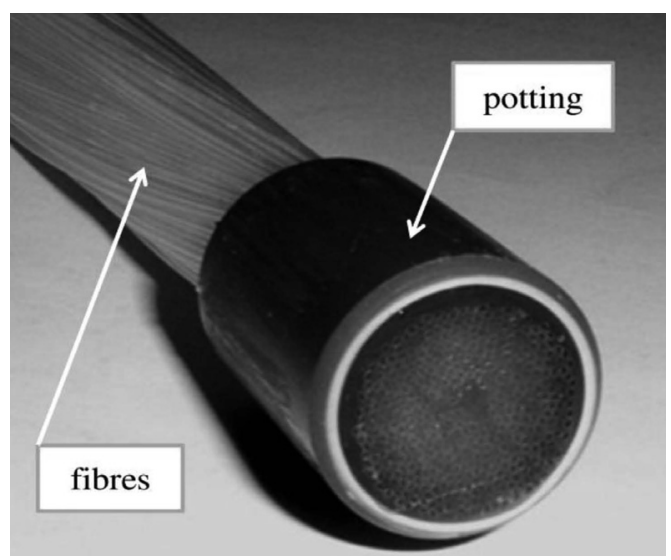

Figure 3: Potting 


$$
k=\frac{Q_{\mathrm{m} 2} \cdot c_{\mathrm{p}} \cdot\left(T_{2}^{\prime \prime}-T_{2}^{\prime}\right)}{\overline{\Delta T} \cdot S}\left(\mathrm{~W} \cdot \mathrm{m}^{-2} \cdot \mathrm{K}^{-1}\right)
$$

For the counter-flow exchanger, the mean temperature difference was calculated as follows:

$$
\overline{\Delta T}=\frac{\left(T_{1}^{\prime}-T_{2}^{\prime \prime}\right)-\left(T_{1}^{\prime \prime}-T_{2}^{\prime}\right)}{\ln \frac{T_{1}^{\prime}-T_{2}^{\prime \prime}}{T_{1}^{\prime \prime}-T_{2}^{\prime}}}
$$

where $T_{1}^{\prime \prime}$ and $T_{1}^{\prime}$ are the temperatures of water entering and exiting the primary circuit $\left({ }^{\circ} \mathrm{C}\right)$.

In the case of exchangers with cylindrical heat-transfer surfaces (pipes or fibres), the thermal capacity may also be expressed using the linear overall heat-transfer coefficient $k_{l}$. The corresponding Equation is as follows:

$$
P=k_{l} \cdot \overline{\Delta T} \cdot l \cdot n(\mathrm{~W})
$$

where $l$ is the length of fibres (m) and $n$ is the number of fibres (1).

The exchanger area $S$ in Equation (1) represents the $\pi \cdot d \cdot n$ product; therefore, the relation between the $k_{l}$ and $k$ coefficients may be described as follows:

$$
k_{l}=k \cdot \pi \cdot d\left(\mathrm{~W} \cdot \mathrm{m}^{-2} \cdot \mathrm{K}^{-1}\right)
$$

The exchanger area may be calculated using the outer $\left(d_{1}\right)$ or inner diameters $\left(d_{2}\right)$ of fibres. If the $d_{1}$ value is used, then the $k$ coefficient relates to the outer surface of fibres, while $d_{2}$ is used for the inner surface.

With regard to the mechanism of heat transport in the exchanger comprising fibres, the overall linear heat resistance $R_{l \text { sum }}$ is as follows:

$R_{l, \text { sum }}=\frac{1}{k_{l}}=\frac{1}{d_{1} \cdot \alpha_{1}}+\frac{1}{2 \lambda_{\mathrm{pp}}} \cdot \ln \frac{d_{1}}{d_{2}}+\frac{1}{d_{2} \cdot \alpha_{2}}\left(\mathrm{~m} \cdot \mathrm{K} \cdot \mathrm{W}^{-1}\right)$

where $\alpha_{1}$ and $\alpha_{2}$ are convective heat-transfer coefficients for the heat convection into the fibres and inside the fibres $\left(\mathrm{W} \cdot \mathrm{m}^{-2} \cdot \mathrm{K}^{-1}\right)$ and $\lambda_{\mathrm{PP}}$ is the thermal conductivity of $\mathrm{PP}\left(\mathrm{W} \cdot \mathrm{m}^{-1} \cdot \mathrm{K}^{-1}\right)$.

Individual fractions in Equation (6) may also be written as individual linear heat resistances, i.e., as follows:

$$
R_{l, \text { sum }}=R_{l, \alpha_{1}}+R_{l, \lambda}+R_{l, \alpha_{2}}\left(\mathrm{~m} \cdot \mathrm{K} \cdot \mathrm{W}^{-1}\right)
$$

Due to a very small diameter, the flow inside the fibres is laminar. For example, for water with the temperature of $20{ }^{\circ} \mathrm{C}$, flowing in a capillary with an inner diameter of $0.2 \mathrm{~mm}$ at a rate of $1 \mathrm{~m} \cdot \mathrm{s}^{-1}$, the Reynolds number does not exceed 200 . The capillary diameter also relates to the hydrodynamic-inlet length $L_{\mathrm{e}, \mathrm{d}}$ and thermal-inlet length $L_{\mathrm{e}, \mathrm{t}}$. For the examined capillaries, this meant that $L_{\mathrm{e}, \mathrm{d}}$ was in the order of $10^{\circ} \mathrm{mm}$ and therefore $L_{\mathrm{e}, \mathrm{t}}$ was $10^{0} \mathrm{~cm}$. This means that almost along the entire length of the capillary, the laminar flow was fully developed. As a result, the convective heat-transfer coefficient $\alpha_{2}$ only depended on the inner fibre diameter and thermal conductivity $\lambda_{\mathrm{m}}$ of the flowing medium. At the constant heat flux through the fibre walls, the following Equation applies:

$$
\alpha_{1}=\frac{4.364 \cdot \lambda_{\mathrm{m}}}{d_{2}}\left(\mathrm{~W} \cdot \mathrm{m}^{-2} \cdot \mathrm{K}^{-1}\right)
$$

With the above-mentioned capillary diameter of $0.2 \mathrm{~mm}$, the $\alpha_{2}$ value amounted to approximately $13 \mathrm{~kW} \cdot \mathrm{m}^{-2} \cdot \mathrm{K}^{-1}$.

Even though a decreased capillary diameter positively affects the intensity of the convective heat transfer, it also increases the pressure loss. The pressure loss caused by friction per $1 \mathrm{~m}$ of a fibre length may be calculated as follows:

$$
p_{z}=32 \cdot \eta \cdot \frac{w}{d_{2}^{2}}\left(\mathrm{~Pa} \cdot \mathrm{m}^{-1}\right)
$$

where $\eta$ is the dynamic viscosity of the medium $(\mathrm{Pa} \cdot \mathrm{s})$; $w$ is the flow velocity $\left(\mathrm{m} \cdot \mathrm{s}^{-1}\right)$.

Equations (8) and (9) indicate that the $\alpha_{2}$ and $p_{z}$ values increase with the decreased diameter, while the pressure loss increases with a squared diameter. In each case, it is therefore necessary to select the fibre diameter so that the pressure loss is acceptable and the $\alpha_{2}$ coefficient value does not exhibit a significant decrease.

The thermal conductivity of the water at temperatures from $20{ }^{\circ} \mathrm{C}$ to $50{ }^{\circ} \mathrm{C}$ changed by less than $7 \%$. This means that the linear heat resistance $R_{l, \alpha 2}$ was almost constant for the given fibre diameter. For a particular fibre diameter, the linear heat resistance of the wall $R_{l, \lambda}$ may also be regarded as a constant.

Therefore, Equation (7) for the given type of exchanger is as follows:

$$
R_{l, \text { sum }}=R_{l, \alpha_{1}}+\text { const }\left(\mathrm{m} \cdot \mathrm{K} \cdot \mathrm{W}^{-1}\right)
$$

This means that the $R_{l, \text { sum }}$ value may only be reduced by reducing linear resistance $R_{l, \alpha 1}$. Higher $k_{l}$ or $k$ values may only be achieved with a more intensive heat transport through the outer side of fibres.

\section{EXPERIMENTAL PART AND RESULTS}

The investigation dealt with atypical designs of heat exchangers consisting of bundles of PP fibres. The thermal capacity of the exchanger was measured using the measuring stand shown in Figure 4.

The arrangement shown above facilitated the measurements of the flow rate of water in the primary and secondary circuits of the exchanger, pressures and temperatures of water at the inlet and outlet of the PCE, i.e. $p_{1}^{\prime}, p_{1}^{\prime \prime}, T_{1}^{\prime}, T_{1}^{\prime \prime}$, and pressures and temperatures at the inlet and outlet of the SCE, i.e. $p_{2}^{\prime}, p_{2}^{\prime \prime}, T_{2}^{\prime}, T_{2}^{\prime \prime}$.

In the first stage of the experiment, a bundle of capillaries was tested with shell-and-tube exchangers. ${ }^{13}$ The exchangers of this type are used in the counter-flow arrangement. The first design of the exchanger is shown in Figure 5. The transparent part of the exchanger, with an inner diameter of $30 \mathrm{~mm}$, facilitated the monitoring of 


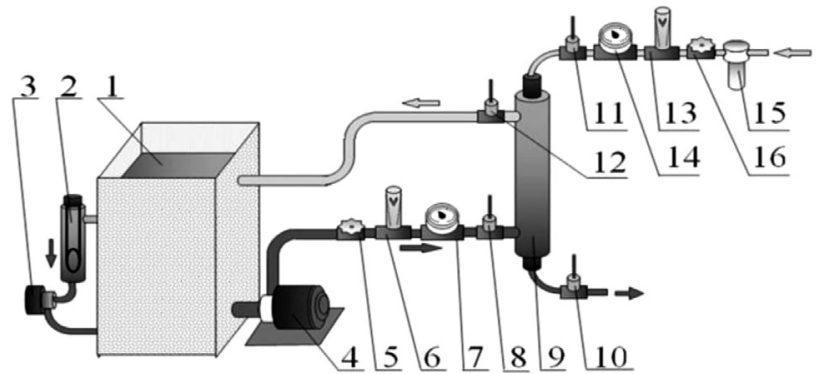

Figure 4: Schematic of the exchanger arrangement in the measurement circuit

The numbers in the scheme represent the following parts: 1 - hot-water tank; 2 - electric spiral body; 3 - pump; 4 - pump in the primary circuit of the exchanger (PCE); 5 - regulation valve in the PCE; 6 flow meter in the PCE; 7 - pressure meter at the inlet of the PCE; 8 thermometer at the inlet of the PCE; 9 - heat-exchanger body; 10 thermometer at the outlet from the secondary circuit of the exchanger (SCE); 11 - thermometer at the inlet in the SCE; 12 - thermometer at the outlet from the PCE; 13 - flow meter in the SCE; 14 - pressure meter at the inlet in the SCE; 15 - water filter in the SCE; 16 - regulation valve in the SCE.

the behaviour of fibres during the experiment. During the tests, fibres did not exhibit any movements; along their entire length, they were touching each other and the inner side of the exchanger body. This reduced the heat transfer between the outer surface of the fibres and the surrounding medium. Considering the information obtained with the performed experiments as well as the above-presented theoretical analysis of heat transport, a new design of the exchanger body was created.

The second exchanger design was based mainly on the following two adjustments:

- Increasing the diameter of the exchanger body from $30 \mathrm{~mm}$ to $50 \mathrm{~mm}$;

- Integrating a tangential water inlet into the exchanger body - see the part marked with a white oval in Figure 6.

During the tests, the exchanger was in a vertical position and the inlet for primary water was in the lower part of the exchanger. The tangential medium inlet produced a strong fibre-whirling effect. It was observed that the fibres were no longer touching the inner side of the exchanger and in the upper part, they took a helical shape. With this type of exchanger, two types of fibres from a bundle were tested - transparent (smooth) fibres and porous fibres. The parameters of one of the tested versions of the exchanger are listed in Table 1.

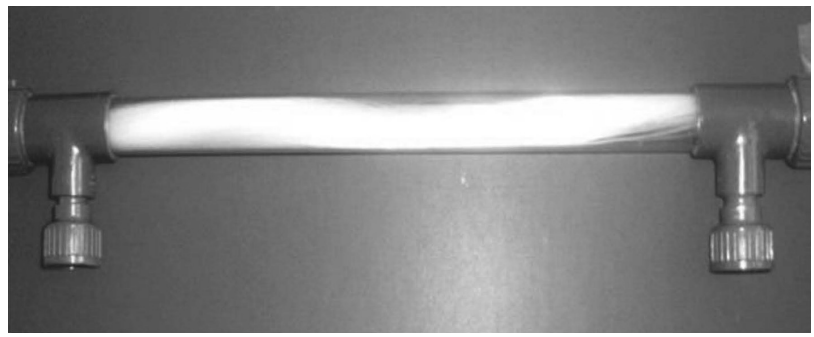

Figure 5: Shell-and-tube exchanger with a radial inlet and outlet

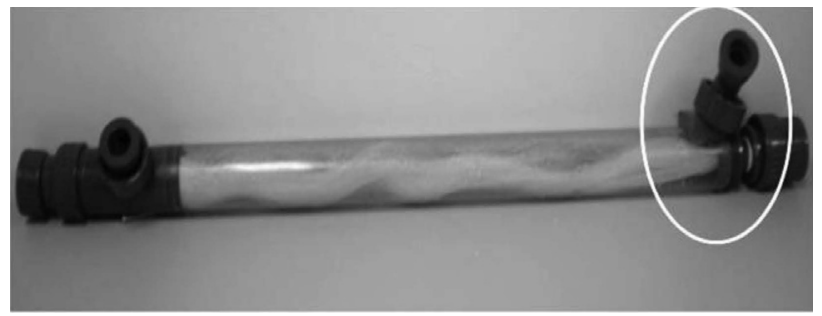

Figure 6: Shell-and-tube exchanger with a tangential inlet

Table 1: Parameters of the bundle of transparent fibres

\begin{tabular}{|l|c|c|}
\hline \multicolumn{1}{|c|}{ Parameter } & Value & Unit \\
\hline Number of fibres in a bundle & 1400 & $\mathrm{pc}$ \\
\hline Length of fibres in a bundle & 680 & $\mathrm{~mm}$ \\
\hline Outer diameter of fibres & 0.275 & $\mathrm{~mm}$ \\
\hline Heat-transfer surface of the bundle & 0.822 & $\mathrm{~m}^{2}$ \\
\hline
\end{tabular}

The measurement results were used to identify the overall heat-transfer coefficient for the volumetric flow rate of secondary water; the identified values ranged from $35 \mathrm{~L} \cdot \mathrm{h}^{-1}$ to $150 \mathrm{~L} \cdot \mathrm{h}^{-1}$. The $k$ value relative to the outer surface of the fibres ranged from $154 \mathrm{~W} \cdot \mathrm{m}^{-2} \cdot \mathrm{K}^{-1}$ to $603 \mathrm{~W} \cdot \mathrm{m}^{-2} \cdot \mathrm{K}^{-1}$. All the versions of the exchanger with porous fibres exhibited as much as a 20-\% lower heat-transfer coefficient.

The use of the tangential water inlet also had certain negative effects. In the lower part of the exchanger, the fibres exhibited tension and adhesion to each other. In the upper part, free fibres were torn away by the liquid flow and carried to the outlet pipe where they caused clogging. This drawback was resolved by installing a perforated seal-in tube into the outlet pipe.

In order to increase the intensity of heat transport through the outer side of the fibres, the exchanger was subjected to additional adjustments. Using a silicone sealant and a waterproof tape, whirlers were installed on the fibres (Figure 7). In addition to this adjustment, a heat exchanger was produced with fibres of the same length and the fibres were adequately loosened, in particular on the area covering $3.7 \%$ of the fibre length. Other basic parameters of the exchanger were identical to those listed in Table 1.

Monitoring was focussed on the thermal capacity of the exchanger with whirlers for the volumetric flow rate of secondary water, which ranged from $30 \mathrm{~L} \cdot \mathrm{h}^{-1}$ to

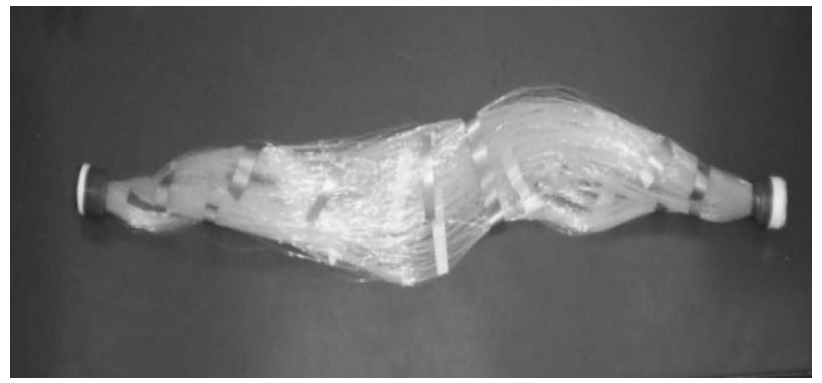

Figure 7: Heat exchanger with whirling elements 


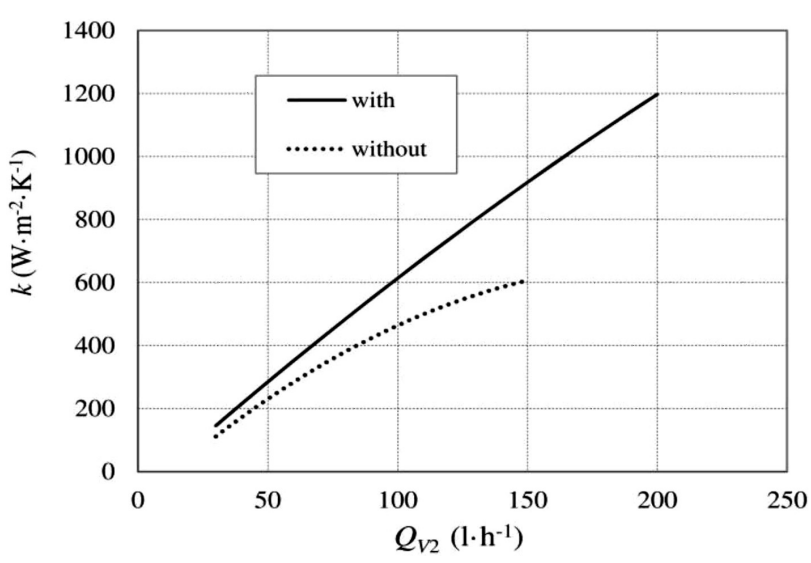

Figure 8: Coefficient $k$ for the exchanger with (without) whirlers

$200 \mathrm{~L} \cdot \mathrm{h}^{-1}$. The curve of the overall heat-transfer coefficient $k$ in relation to the changing $Q_{V 2}$ is shown in Figure 8. For the purpose of comparison, the plot also contains the curve of the $k$ values for the same exchanger, but without the whirlers.

\section{DISCUSSION}

Initial experiments with the shell-and-tube exchangers demonstrated that designs with a radial inlet and outlet for primary water do not provide an efficient heat transport. In concordance with the theory, it was confirmed that better results were achieved with fibres with smaller diameters. The key experimental part was therefore carried out with the exchangers containing 1400 fibres with an outer diameter of $0.275 \mathrm{~mm}$ and a length of $680 \mathrm{~mm}$.

The curve of the values of the heat-transfer coefficient for the outer side of the fibres in relation to the changing thermal capacity of the exchanger is shown in Figure 9. The results indicate that the whirlers are very important. For example, at the thermal capacity of $4500 \mathrm{~W}$, at which the whirlers are used, the $\alpha_{1}$ coefficient

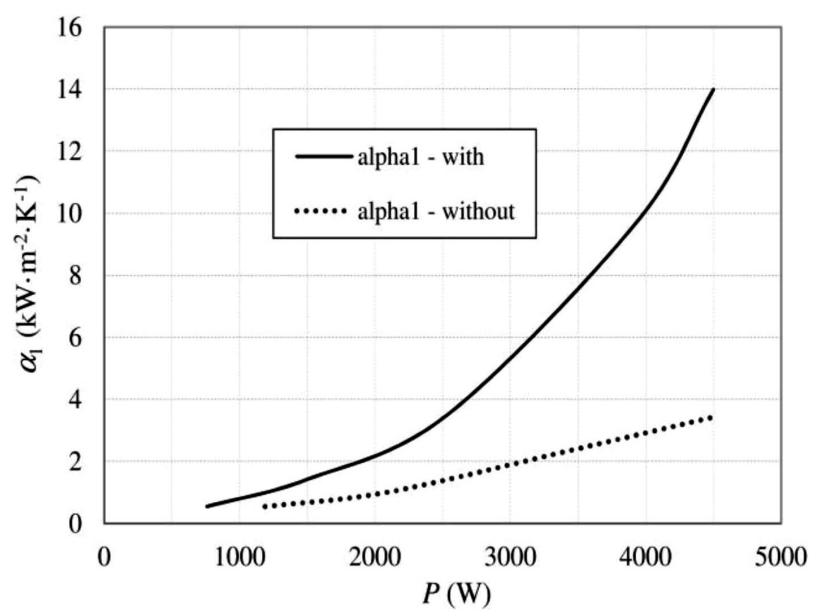

Figure 9: Heat-transfer coefficient for the primary side of the exchanger

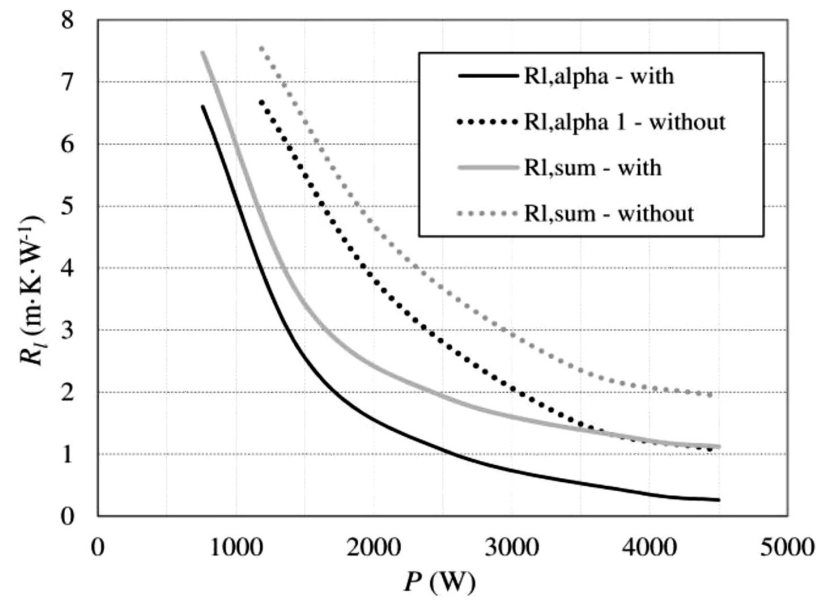

Figure 10: Linear thermal resistance

is almost 4.1 times higher than that of the exchanger comprising the fibres without an adjustment of their outer side. This practically means that with the exchanger with whirlers, a certain thermal capacity may be achieved with a significantly smaller difference between the temperatures of the primary and secondary media, or with a smaller heat-transfer surface area.

Figure 10 shows the curves of the values of linear heat resistances $R_{l, \text { sum }}$ and $R_{l, \alpha 1}$ in relation to the increasing performance of the exchanger. They indicate that whirlers have fundamental effects on the overall resistance. For example, at a thermal capacity of $2500 \mathrm{~W}$, the exchanger with installed whirlers exhibited almost 30-\% lower overall heat resistance; correspondingly, the heat-transfer coefficient increased.

The curves in Figure $\mathbf{1 0}$ clearly demonstrate the validity of Equation (10). The changes in the overall linear heat resistance only depend on the heat resistance of the outer side of the fibres. This applies equally to exchangers without whirlers as well as those with whirlers.

\section{CONCLUSION}

Literature sources ${ }^{6}$ state that the overall heat-transfer coefficient of the fibres made of polypropylene might amount to as much as $1200 \mathrm{~W} \cdot \mathrm{m}^{-2} \cdot \mathrm{K}^{-1}$. The tests performed with heat exchangers confirmed the validity of such a hypothesis, but only for the transparent fibres and high intensity of heat transport through the outer side of capillaries. The result of adding whirlers to the primary side of the exchanger was a significant increase in the value of the overall heat-transfer coefficient $k$. For the transparent fibres with the outer diameter of $0.275 \mathrm{~mm}$ at the volumetric flow rate of $Q_{V 2} \in\langle 35,150\rangle \mathrm{L} \cdot \mathrm{h}^{-1}$, the $k$ coefficient increased from $27 \%$ to $51 \%$.

Several other exchanger designs were examined, but they are not mentioned in this article. For all of them, it was confirmed that the adjustments described herein had a positive effect; in particular, they increased the intensity of the heat transfer through the outer side of the 
fibres. Experimental analyses of exchanger designs with polypropylene fibres demonstrated a possibility to regulate heat transport in this type of exchangers and thus regulate their performance.

\section{Acknowledgment}

The paper was produced as part of VEGA No. 1/0626/20 and SP 2020/34-FMT VŠB TUO projects.

\section{REFERENCES}

${ }^{1}$ E. Bartuli, M. Raudenský, Numerical Investigation of Heat Transfer on the Outer Surface of Polymeric Hollow Fibers, Proc. of the $24^{\text {th }}$ International Conference on Materials and Technology, Portorož 2016, 37-37

${ }^{2}$ R. Gallik, M. Dohnal, Mechanical Engineering (in Slovak), special edition (2009), 61-62

${ }^{3}$ M. Čarnogurská, M. Př́íhoda, M. Lázár, N. Jasminská, R. Gallik, M. Kubík, Journal of Mechanical Engineering, 62 (2016) 6, 381-384, doi:10.5545/sv-jme.2015.3202

${ }^{4}$ W. Makiela, J. Swiderski, K. Stepien, MM Science Journal, 1 (2020), 3857-3860, doi:10.17973/MMSJ.2020_03_2019137
${ }^{5}$ K. Weiß, I. Astrouski, M. Reppich, M. Raudensky, Chem. Eng. Technol., 41 (2018) 7, 1457-1465, doi:10.1002/ceat.201700014

${ }^{6}$ D. M. Zarkadas, K. K. Sirkar, Eng. Chem. Res., 43 (2004) 25, 8093-8106

${ }^{7}$ A. A. Tseng, M. Raudensky, SF Journal of Material and Chemical Engineering, 2 (2019) 1, 1-7, https://scienceforecastoa.com/Articles/SJMCE-V2-E1-1012.pdf

${ }^{8}$ T. Kroulíková, T. Brožová, E. Bartuli, M. Raudenský, Experimental Verification of Polymeric Distillation Unit, Proc. of the $25^{\text {th }}$ International Conference Engineering Mechanics, Svratka 2019, 211-214, doi:10.21495/71-0-211

${ }^{9}$ E. Bartuli, T. Kroulíková, Testing of Polymeric Hollow Fibre Heat Exchanger with Crossed Hollow Fibres, Proc. of the $5^{\text {th }}$ World Congress on Mechanical, Chemical, and Material Engineering, Lisbon 2019, HTFF 143, doi:10.11159/htff19.143

${ }^{10}$ J. H. Lienhard IV, J. H. Lienhard V, Heat Transfer Textbook, $4^{\text {th }}$ ed., Phlogiston Press, Cambridge 2012

${ }^{11}$ M. Příhoda, M. Rédr, Sdílení tepla a proudění, SNTL, Praha 1998, 680 (in Czech)

${ }^{12}$ V. Janostik, L. Hýlová, D. Manas, M. Manas, L. Gajzlerova, A. Mizera, M. Stanek, Local mechanical properties of irradiated cross-linked polypropylene, Mater. Tehnol., 52 (2018) 1, 31-33, doi:10.17222/mit.2017.097

${ }^{13}$ G. F. Naterer, Heat transfer in single and multiphase systems, $1^{\text {st }}$ ed., CRC Press, 2019, 640 